KONSTRUKTIVISME, Vol. 7, No. 2, Juli 2015

p-ISSN: 1979-9438, e-ISSN: 2445-2355

FKIP Universitas Islam Balitar, Blitar

Web: konstruktivisme.unisbablitar.ejournal.web.id

\title{
ALTERNATIVES TO ATTRACT AND MAINTAIN TEACHERS IN RURAL SCHOOLS IN INDONESIA IN CONTEXT OF STRINGENCY
}

\author{
Soebiantoro \\ Balitar Islamic University \\ JI. Mojopahit 12A Blitar \\ Email: sbiantoro67@gmail.com
}

\begin{abstract}
This paper describes problems pertaining teachers assigned in the rural areas in the whole Indonesia are inconvenient to work and leave the sites. This paper argues that salient problems exist in terms of triviality field condition, performance motivation, incentive, and lax of implementation management. Evidently, policy made by the decision makers in upper to the lower level of policy makers contributes ineffective supports of teachers' needs and necessities in the sites. The effectiveness of Law on Teacher and Lecturer is problematic stipulated for the teachers problems in rural and remote areas.
\end{abstract}

Keywords: remote school, career discrepancy.

\begin{abstract}
Abstrak
Makalah ini membahas tentang permasalahan-permasalahan yang membuat guru-guru di pedalaman Indonesia tidak mau bertahan tinggal di tempat di mana mereka ditugaskan. Permasalahan bermula dari kondisi lapangan, semangat kinerja, insentif, dan manajemen implementasi yang kurang mendukung. Berbagai usulan dilakukan tetapi belum memuaskan hasilnya. Terbukti bahwa kebijakan yang dibuat oleh policy maker baik di level bawah maupun level pusat kurang mendukung. Walaupun UU tentang guru dan dosen sudah diberlakukan di lapangan masih terdapat kendala yang cukup besar untuk mengatasi permasalahan guru terpencil.
\end{abstract}

Kata-Kunci: sekolah terpencil, kesenjangan karir.

TEACHER supply and distribution in rural schools has faced serious problem. It is not only because there have been poor co-ordinations between school at lower level and central government at upper level of hierarchy in supplying and distributing teachers but also the teachers' interest to teach in isolated schools are very low. Even, teacher recruitment is carried out by central government annually by involving districts of National Education Department office, but the new recruit hasn't been distributed evenly. Consequently, many teachers are posted in particular schools, indeed in urban schools that are mostly desired by every teachers, while the isolated don't get enough portion of new recruits. 
Needless to say, by which most teachers, who are appointed in isolated schools, are rarely prepared with any pre-service training either from the university as production agent of teacher or government as a main distributor. Whatever the reasons, approaches and analysing the main issues suffering isolated teachers for solution is needed to actualise the goal of national education. Then the most crucial are rural courses should be introduced by or in the universities as preparation.

According to Michele in her lecture explanation on 27 November 2001, the major reason why those teachers are not attractive to teach in rural schools is mostly because of feeling isolated. Then, indeed, it refers to feeling of the isolated working condition, income, career, promotion, professional development, and future of their family is the facts of rural life.

The teacher supply and distribution actually involves all hierarchical levels on National Education Department except school. This is meant to build effectiveness and efficiency up. In the process, this project has to be embarked with fully intervention and involvement of schools where teachers are needed. In turn, the new recruits will be placed and work in the right places with good co-ordination through departments in sub-districts, districts, and provincials as well as central National Education Department.

This paper will discuss various alternatives that are able to attract and maintain teachers in rural areas. The beginning section will discuss introduction. Then, the second part will focus on the main issues faced by teachers in rural schools such as; working condition, teacher recruitment system, teacher professional development, teacher career and promotion and teacher income. In the following section will elaborate the approaches or alternative solution that includes the issue of involving teachers in social activities, decentralisation and the advertisement, provision of equal opportunity in teacher professional development (quality base professional development management). Then rewarding good service in teacher administration (quality base service improvement) and giving teacher training in farming and agriculture skills are being placed in the last part of this section. In the end of this paper will sum up the issues as the reflection.

\section{MAIN ISSUES IN RURAL SCHOOLING REGARDING TO TEACHER}

"For the moment though, it is important to establish what are seen to be some of the important issues facing teachers, especially beginning teachers, working in rural, remote and isolated schools. In particular, it is important to establish what are some major issues attracting and retaining teachers in these schools." (Yarrow, A. et al, 1999:5)

Most teachers who are firstly appointed in remote schools will think for hundred days to do their job, particularly participants who come from urban areas or big cities that usually tend to have luxury way of life. In contrast, the categories and the amount of salary have been standardised based on the government national policy. It is often referred to the level of formal education that they get rather than professional capacity. 
Disappointingly, their image either on the village life or school setting is rarely good. Regarding to teacher as a profession, the Indonesian philosophy of teacher suggests that every teacher should be aware of what his or her main role without any material consideration.

Before presenting the main issues, it is useful to say that Indonesian government has interesting essential political way on how to attract teacher's interest and maintain them in isolated area schools. Since 1980s teachers have been awarded an enormous degree 'The Unrewarding Hero or No service Medal Hero' (Pahlawan Tanpa Tanda Jasa in Indonesian) by Indonesian President; Soeharto. It is generally believed, particularly in some areas in Indonesia, that teacher is very magnificent profession.

Hopefully, the excellence of this attribute has been able to encourage teachers understanding of what their main roles are without considering financial benefit and where they are employed. With a conceptual point of few that teacher is figure of social change, it can bring his or her strong motivation to perform a service to the intellectual life of the nation. For instance, in 1960-1970 some teachers in Java didn't earn salary for their job. Moreover they should be willingly to spend their money for teaching learning needs such as petroleum for lighting and chalk. Blackman, C.A. (1989: 3) argues that "The teacher is not only a professional, but a professional person with a unique life history and psychological being".

Besides the motivational expression above, the significant contextual issues facing teachers in rural and remote schools should be analysed for solution in order to attract and gain teacher's interest. The following common sense on teacher problems in remote areas are; working condition, teacher recruitment system, teacher professional development, teacher promotion and career, and teacher income. Analysing the significant classical problems above for solution is very crucial to attract and maintain these teachers.

\section{Working Condition}

In term of geographical condition of rural areas in Indonesia, it has been clearly described by Sudidjarto (1980) et al as follows;

"Communication and transportation are particularly difficult. The inner regions of Kalimantan contain dense forests and swamps, with few roads available, so that remote schools can not easily be furnished with textbooks, curriculum guidebooks, in-service education for the staff, or directives about new regulation. Mountain areas of Sumatra and Irian Jaya are also difficult to enter. Access to many of smaller islands is gained a most circuitous manner - it requires taking a ship to large island, chartering a boat to a medium sized island, then boarding a smaller boat which travels once every three or four months to the small island that is the object of the trip." (Soedijarto et al, 1980:49) 
Even the development programs have been achieved since 1960s, but there haven't been better changes in these areas. Generally, the electricity is not provided in this rural areas even they are connected to the national grid, power supplies are unstable and unlikely (Harber and Davies, 1997:16). Surprisingly, this remoteness has hidden thousands of ethnic groups, various culture, customs, religions, local language, and lower education level that possibly provide problems for the new comer. Nevertheless, the rural community often underestimate the value of formal education, even most of them respect teaching profession so much. So considerable social approaches should be taken apart to increase their concern and awareness.

From the point of view of health protection, rural environment has dangerously threatened new teachers' survival but not always. ILO (1991:107) gives evidence that a teacher is possibly prone to illnesses, such as frequent sore throats, caused by the necessity of explaining the material in the loud voice over long period, might be the whole day of teaching time for a class teacher, sometimes in confined atmosphere. The other possibility is that more serious as the risk of contracting diseases in housing areas where domestic sanitary conditions are unsafe. Disappointingly, health service is not evenly well provided for either teachers or public in general even they (state teachers) have been entitled to regional medical service (ASKES; health insurance provided by government nationally).

\section{Teacher Recruitment System}

It is really big problem to provide adequate teachers in rural areas. The major reason is because most of the participants are reluctant to be appointed in rural schools. The very classic reasons are usually spoken such as no additional money, no healthy housing, irregular salaries and insignificant transports. Bishop (1989) explains as:

"...there are far more shortages of teachers in the rural areas than in towns. Because rural living conditions housing, hygiene, sanitation, etc. - are bad and because the pay is inadequate, recruitment of teachers for rural schools in general and female teachers in particular, is a major problem in many developing countries. Commitment and sense of vocation are usually not enough to counteract the attractions of the towns." (Bishop, 1989:47)

The bureaucratic procedure of being a teacher has been taken part. Competency test has been run to provide teacher with adequate skills. None of people graduated from schoolteacher training can become a state teacher without taking national teacher recruitment test. Many official requirements offered by central government in Jakarta to meet by professional participants such as they should sign in an agreement letter to 
certify that they are ready employed wherever the schools are as long as they are located in Indonesia.

Depressingly, teacher candidates tested in Java and Bali, who doesn't know the real nature; geography and culture, around school setting where they are being placed, are usually exported/transferred to many isolated sub-districts in four biggest islands; Kalimantan, Sulawesi, Sumatra, and Irian Jaya. Even test recruitment is taken place in some provinces within these islands but mostly the job seekers come from Java and Bali as well. It doesn't mean that process of importing teachers supply will cut off there, but it is still continued. It is because Government policy retains chance of mutation to urban schools to teacher appointed in remote schools after they work within two years in service. Some take advantages of this government offer.

\section{Teacher Professional Development}

Starting from the belief that mostly teachers in rural schools are not qualified or under-qualified, the educational strategies to improve their knowledge and outlooks are important. As Harber and Davies (1997:16) state that in developing countries, particularly in rural areas, schools often to function with both unqualified and underqualified educational staff. It is very difficult to send qualified teachers. Fidler (1993:7) argues that based on the result of the 1988 survey, it was around $16 \%$ up to $20 \%$ of teaching was being carried out by those who did not have a post $A$ level qualification in the subject they were teaching or subject closely related to it. Badly, it was about $75 \%$ of 16.000 teachers' qualification of primary school in East Kalimantan graduated from Senior High School (Suara Pembaruan, 2 March 1999). The notion of how to improve teacher personal knowledge and skills in accordance with the teaching quality is very crucial, in turn this will bring the quality base improvement in school out puts. The component and conceptual instruments should be equally well provided.

Refer to the Indonesian geographical condition as described before, it can be highlighted that how difficult to reach deserts, thus the information from regional or provincial National Education Department will be so difficult to reach. As a result, teachers in these areas haven't opportunities to any kinds of training, short course, and upgrading. Then the improvement of the teacher professional development program is totally zero. In reality, for instance my own experiences, the officials of regional office are usually reluctant to contact teachers in those areas for teacher training or upgrading. The majority is because of unreachable distance, consuming time, insufficient or financial budget and other classical reasons, as the possible alternative they ask those who teach in urban school as the representative. This manipulation is intended to how the project of teacher training is successfully run in order to get financial benefit from this project. Therefore, Tilaar, H.A. (1998: 315) agrees that mostly teacher training or upgrading is extremely ineffective, unqualified and unstructured well, it has been wasting time and money. 


\section{Teacher Career and Promotion}

Based on the government policy no. 3, 1980 stipulated that every government employees have a right to apply their higher degree or entry level (jenjang kepangkatan in Indonesian) as reward from the government within every two years for teachers and particular period for other civil servant. Like other countries, Indonesia has a structure career grade by which all posts within a particular grade carry the same salary scale. In principle, this should lead to equity between different kinds of work. On the other hand, grading of post and the requirement of certain levels of qualification for entry to particular grade may lead to senior posts of course with higher salary scale. In practical administration, teacher grade or entry level determined with credit point system. This can be applied and proceeded every two years or more depending on his/her academic and teaching qualification completion through provincial National Education Department office.

The case is that most teachers not only for those who come from deserts but also from urban or town suffer from poor administration service in provincial or district office of National Education Department. Whereas, they often spend many days 'leave the student learning alone without teacher' and much money for travelling to the office but they only get stressful service from provincial official. In fact, when the teachers intend to apply the credit points deal to entry level scheme and regular increment, the official usually welcome in service for the particular well-recognised teachers and rupiahs (Indonesian Currency) are ready for them. If they aren't, no good service for them. It is really impossible the officials recognise these rural teachers easily. In principle, the transaction should be done to ensure that their application is being administered. Hoogvelt (1976) cited in Harber and Davies (1997 argues;

"Furthermore the customary exchange of gifts was often normal and integrated part social behaviour but with the change to a modern bureaucracy 'Legitimate gifts' become 'disguise bribes' and expected by officials before a service will be performed." (Hoogvelt in Harber and Davies, 1997:102)

In daily practice, the degree of nepotism, collusion and corruption through out the administration service is very apprehensive about. My own disappointing administrative experience can be taken as an example in which it was my first year in service. I didn't earn my three months salaries. As inconsiderable reasons is that these monthly salaries used to pay the administration fee as a new teacher even it is officially no fee at all.

Teacher promotion is more determined by academic qualification, official grade/level and particular test. Badly, a teacher is being impossible to become a head teacher particularly rural teacher even he/she passes the principal recruitment test if he/she isn't able to bargain the transaction of this managerial position and interweave a good channelship with key authority players in provincial office. Mostly urban teachers, who domicile 
near to this office and possibly are closer to the manager selector as well as determiners, have broader opportunities to gain this position 'head teacher' than the rural one.

This real silent or undetectable phenomenon has been commonly practised and faced by teachers in bureaucratic life without any exception from the central government includes National Education Department until sub-district level. As Harber and Davies (1997) describe;

"For Riggs the persistence of strong ties and pressures of extended family in prismatic society and the need for sala officials to reinforce their power position by recruiting staff on whom they can rely, are factors which can also result in nepotism in public appointments and the behaviour of public officials." (Harber and Davies, (1997:103)

\section{Teacher Income}

Harber and Davies (1997:16) argue that teachers' salaries in developing countries have declined in real terms. In principle, there is no difference between teachers' salaries in rural and in urban areas in Indonesia. Officially, as stated at the previous paragraph that the amount of salaries based on the teacher's particular grade/level. Basically, all posts within particular grade/level carry the same salary scale regardless with where teachers are appointed. The entry level itself has to be accelerated to the academic qualification (educational background) that teachers pursued.

In reality, mostly teachers in rural areas do not have adequate skills or lower education than the urban one (see section $\mathrm{C}$ ). Consequently, they face difficulties to arrange the credit point for their grade not only because of academic reason but also administration service itself. Then, it is inevitable that they will be entitled on the lower level and lower salaries. In East Kalimantan for instance, rural primary school teachers earn incentives around 3.250 rupiahs ( $£ 0,20$ pence) per-month (Suara Pembaruan, 02 March 1999). Disappointingly, in reality for those in rural areas, teachers' salaries are often paid late because of many reasons such as transportation difficulties, unavailable banks or financial services centre, and natural disasters. So they frequently receive the salaries every three months or might be more. Ironically, financially greedy officials often cut off these salaries for personal benefit (Suara Pembaruan, 02-03-1999).

ILO (1991: 110) describes that 'In fact, the post can be so "underprivileged" that teachers are obliged to live away from their family. Furthermore, they have less opportunity of finding secondary employment, which is so often needed to supplement teaching salaries'. According to Hurst and Rust (1990:153) a large number of teachers particularly in urban areas in Indonesia maintain at least two or three teaching position that allows them to earn additional income to cover basic costs. But it will be impossible for teachers in rural areas. 


\section{ALTERNATIVE SOLUTIONS Involving Teacher in Social Activities}

"Pairing teachers up with a local a community mentorship arrangement with the mentor helping to bridge the gap between the newly arrived and old timers in the community" Lunn (1997) cited in Yarrow et al (1999)

Accepting the idea that rural teachers are part of local community where teachers spend his/her daily life with, teacher involvement in every social activity is likely helpful to prevent feeling isolated and homesick retention. As it is suggested by Lunn (1997) cited in Yarrow et al (1999) that introducing teachers to members of a churh, special interested clubs and involving them in this social activities is very significantly. In Indonesia, for instance, the involvement can be in the form of local festival activities, village celebration, village harvest, religious parties, health and education illumination, and mutual help (gotong rotyong in Indonesian). These activities will be able to keep teachers busy and more familiar with local community. Of course, in this case village leaders, religion leaders and ethnic groups' leader as the government representatives at the lower level play the important role in this concern.

To provide good health, the ideas of health illumination in which teachers work together with local community to develop clean environment and traditional pharmacy are important. Moreover, the government program of distributing village doctors should be monitored and properly organised.

\section{Decentralisation/Advertisement in Teacher Recruitment}

It is impossible to judge that the recruitment system above is wrong, but this is not effective in term cost and teacher placement as well. This system requires, of course, highest cost for facilitating, accommodating and transporting new teachers in and to new places in which it spends few weeks to reach the intended places. Moreover, it will be stressful for them to adapt to a new place with new culture, customs, norm, climate, and situation. Tilaar, H.A. (1998:315) argues that the process of teacher recruitment should be totally revised to be more tight selection in order to achieve the required teacher qualification. In turn, hopefully every teacher will be able to carry out his or her sublime task as the agent of change wherever he or she will be assigned.

So local or regional human resources recruitment approach (decentralisation teacher recruitment) will be the answer of effectiveness, efficiency, village development, and achieving teachers' attractiveness because at least this will offer cheap transportation, accommodation and continuity of educational development in that village. It is also apart of the implementation of law no. 22, 1999 about regional autonomy. It means that local recruitment system provide the high proportion of autonomy to each districts or at least to each schools to round up new teachers based on the school need. 
Dodds (1993:27) suggest that governing bodies have to be closely involved in teacher recruitment and retention. In addition he says that teacher recruitment is an enormous responsibility which now falls on schools and schools should be involved in teacher training. MOEC (1999) explain as follows;

"....the recruitment of new teachers would constitute a radical departure from current procedures. At present, candidates are first selected for recruitment to the civil service and only subsequently placed as teachers. An attempt is made to place new recruits at school near to where the live, but close matching rarely possible, especially for posting to isolated schools. Furthermore, the preferences of the applicants are not consulted: placement decisions are made by district-level (sometimes provincial level) officials who often lack firsthand knowledge both of the recruits and of schools where they are to be placed. In consequence, many if not most of recruits posted in teacher-shortage areas do not wish to work there. In turn, this generates enormous pressures for transfers: within a relatively short period, a substantial proportion of the recruits has moved to schools in more favoured areas." (MOEC, 1999)

In the process, enticing advertisements, that include clear description of school characteristics where the participants will be placed, is very significant. Dodds (1993:24) believes that recruitment and promotional material was essential. According to Earnshaw (1993:62) the vacancy announcement will be able to give the prospective applicants their impression of the school. It is important to enclose clear information regarding to the career, promotion, and teacher development to attract the teacher candidates.

On the other hand the autonomy will at least minimise teachers' stress or culture shock from village life, it is meant that they are easily familiar with the new place. Lunn (1997:48) cited in Yarrow, A. et al (1999:6) believe that the retention of teachers such as the desire or need to return home and dissatisfaction with teaching or living in rural and remote areas will affect teachers' attractiveness. There has been a traditional philosophy among people in Indonesia especially in Java and some others areas that "makan enggak makan yang penting ngumpul" (however the condition of life, food provided or not provided, living together with family is the most important).

\section{Equal Opportunities in Teacher Professional Development}

The system of teacher training should be totally improved to give equal opportunities for the isolated teachers. Pepin (1995) cited in Glover and Law (1996: 27) argues that every teachers has right to pursue professional development and duty to update their knowledge through formal two inservice strands: continuing training (upgrading and updating 
professional skills and knowledge) and additional or qualifying training that allows for certificate learning. Teacher training is very significant for the improvement of teachers' skill in terms of improving the quality of education. It is clearly expressed by OECD as follows;

"Teachers are the necessary, indeed the most necessary, ingredients of quality but still not sufficient to guarantee it. They should be given, and should accept, a large measure of responsibility but they cannot be held solely accountable. Their contribution must be understood in terms of the curricular, organisational, and social context in which they work. It needs to be prefaced too by the understanding that that contribution depends upon the establishment of condition conducive to sustained high levels of morale and motivation and the full exercise of professional development." (OECD, 1990:10)

Moreover, Glover and Law (1996:21) believe that institutional performance, teaching quality and school improvement and school effectiveness, school improvement, and school effectiveness issues means that professional development is a potentially important strategy for achieving higher standards.

Therefore, the most relevant alternatives for improving teaching profession in developing countries, especially in rural areas, are to offer regular inservice training, supply-programmed material and use interactive radio instruction (Lockheed and Verspoor, 1991 cited in Harber and Davies, 1997:134). It means government should put remote teacher's professional development as the priority in educational development. So the gaps between teacher in rural and urban areas will be avoided.

\section{Rewarding Good Service for Teacher Career Management}

Considering the illustration of teacher administration phenomenon described above, giving better service in rural teachers' career and promotion at least in the procedure of teacher credit point apply without any collusion and nepotism will encourage teachers' motivation and satisfaction in doing their tasks. It will be able to minimise the burden on their shoulder. Nathan (1986:86) argues that salary and promotion are the most obvious ways of making an individual feel valued because it shows everyone that the recipient is regarded as worthy of reward and acts as recognition of merit or effort. Thompson (1990:142) suggests that the career and promotion is should be sufficiently systematised and engaged in by administrative procedures which take account of formal qualifications and length of service that resisted from corrupt, collusion, and nepotism practice.

The range of this system should be cut off to avoid 'No Money No career' and 'No Friendship No Promotion'. As the new Indonesian government under a female president Megawati Sokarno Putri who is extremely concerned to say war against 'Collusion, Corruption, and 
Nepotism' as the first step to awake from multi-serious crisis than has been undermining Indonesia since a few years ago.

\section{Teacher Training in Particular Skills: Farming or Agriculture}

Initially, as a consideration is when the process of teacher recruitment is properly decentralised and well advertised as initiated above, then participants clearly informed about the real conditions of rural school that they preferred. So, contextualising farming and agriculture experience is very significant and applicable for the teachers in village. It needs friendly collaboration between local governance and local villager to retain farming and agricultural practice. To improve the quality of teacher's life economically, at least teacher has to have experiences to cultivate the fields or to look after sheep, cows, and poultry husbandry. Bishop, G. (1989:151) suggests that 'the skills needed for survival and for earning a living in villages and rural towns are different from those needed in towns and cities. The handyman village artisan (usually a part-time farmer) requires not only variety skills but also much ingenuity in applying them'.

Most teachers in rural, who are skilful in agricultural and farming sector, are able to live together among villagers. Economically, they are successful to provide their daily needs that generally are readily available and inexpensive provided by local community to support the family, of course, without ignoring teaching as the main duty. But some of them, who might be unskilful and sluggish, are usually suffering from additional income. Interestingly, accommodation, water, vegetables, fruit and other commodities are often free of charge from local community. Based my own experiences, for instance, teacher is like 'a temporary king' whatever I want is readily served by local society. When I need water to cook and take a bath, some student's parents ask happily their sons to help bringing water for me, even it takes a mile walk.

In addition, Hurst and Rust (1990:153) emphasise that the teachers in developing countries typically supplement their salary with additional income and resources from private small farms and business, for instance in Indonesia. On the other hand, it also affects their ability in teaching learning process. Taylor, P. and Mulhall, A. (1997:3) states that teacher with little or no knowledge of agriculture, and lack of land at the school, may be constraining factors to the use of agricultural examples in the teaching of the other subjects areas.

To improve the teacher income regardless of monthly salary, agriculture and farming training for rural teacher particularly for those who assigned from the city becomes increasingly important as the conceivable alternatives to gather success of life in the village.

\section{REFLECTION}

Education is the responsible of all Indonesian people. The constraints in the implementation have to motivate the educator to reach improvement for the best future. In one aspect, all true phenomenons dealing with rural teachers' complaints should be analysed and learnt by policy makers and authority players to retain alternative solution. Mainly the major issues are working condition, recruitment system, professional 
development, career and promotion, and additional income. Beaurocratically, the key authority players should be seriously hand in hand with all social aspects to find resolution for education in rural areas in context of teacher. It is not only enough to address and delegate this problem to head teacher who possesses higher authority at school level. While mostly they live in the towns. To strengthen co-ordination, collaboration, inspection, and provide satisfactory administration service with reluctance to do 'Collution, Corruption, and Nepotism are considerable and brilliant steps. Critically, comprehending rural teachers' everyday life it seems necessarily to say that the power players should recognise closely teachers as human being and treat them like human as well.

\section{REFERENCES}

Bishop, G. 1989. Alternative Strategies for Education. London: Macmillan Publisher Ltd.

Blackman, C.A. 1989. Perspectives on Teacher Professional Development: Issues in Professional Development; Continuing Agenda (1-18). London: The Falmer Press

Dodds, J. 1993. Recruitment of Teachers: The Work of TASC. (p.21 - 27) Essex: Longman

Earnshaw, J. 1993. Taking Recruitment Seriously: The Headhunters Approach (p.60 - 71) Essex: Longman

Glover, D. and Law, S. 1996. Managing Professional Development in Education. London : Kogan Page

Harber, C. and Davies, L. 1997. School Management and Effectiveness in Developing Countries. London: Cassel

Hurst, P. and Rust, V.D. 1990. The Quality of Education And The Working Conditions of Teachers (p.151 - 170). London \& New York: Garland Publishing, Inc.

MOEC. 1999. Teacher Supply, Training and Professional Development: Getting the Teachers in the Right Places. WWW.pdk.go.id

MOEC. 2000. School Base Management. Jakarta: Directorate General Secondary Education

Nathan, M. 1996. The Headteacher's Survival Guide. London: Kogan Page Limited

OECD Publication (1990) The Teacher Today. Paris

Soedijarto, Moloeng, L., Suryadi, A., Mahmud, D., Pangemanan, F., Tangyong, A.F., Nasoetion, N. \& Thomas, R.M. 1980. Schooling in the Asean Region: Indonesia (p. 47-96). Oxford: Pergamon Press.

Suara Pembaruan (Edition 02 March 1999) Teaching Profession is Decreasingly Preferred in East Kalimantan. Jakarta: Suara Pembaruan Press

Taylor, P. and Mulhall, A. 1997. Contextualising Teaching and Learning in Rural Primary School: Using Agricultural Experience. Volume 1 Serial No.20 London: DFID

Tilaar, H.A.R. 2001. Agenda Reformasi Pendidikan Nasional (The Agenda of National Education Reform). Magelang: Indonesia Tera Publisher 
Soebiantoro. 2015. Alternatives to Attract and Maintain Teachers in Rural 97 Schools in Indonesia in Context of Stringency. Konstruktivisme, 7(2): 85-96.

Thompson, A.R. 1990. Making The Best Use of Teachers: Deployment Issues. (P.123 - 148) London \& New York: Garland Publishing, Inc.

Yarrow, A., Ballantyne, R., Hansford, B., Herschell, P. \& Millwater, J. 1999. Teaching in Rural and Remote Schools: A Literature Review. Teaching and Teacher Education journal. 